\title{
EVALUATING TREES FOR SALTWATER SPRAY TOLERANCE FOR OCEANFRONT SITES
}

\author{
by Bonnie Appleton, ${ }^{1}$ Roger R. Huff, ${ }^{2}$ and Susan C. French ${ }^{3}$
}

\begin{abstract}
Trees growing along the major resort area thoroughfare of the city of Virginia Beach are subjected to saltwater spray from the Atlantic Ocean. Despite the city's desire to plant trees for shade along this thoroughfare, none of 8 species that were reported to be salt tolerant and that met city design requirements were aesthetically acceptable after 1 year in moderate and high wind exposure locations. Species tested were loquat (Eriobotrya japonica), thornless honeylocust (Gleditsia triacanthos var. inermis), Chinese flametree (Koelreuteria bipinnata), goldenraintree (K. paniculata), fruitless sweetgum (Liquidambar styraciflua 'Rotundiloba'), dwarf southern magnolia (Magnolia grandiflora 'Little Gem'), sweetbay magnolia (M. virginiana), and lacebark elm (Ulmus parvifolia 'King's Choice').
\end{abstract}

Key Words. Salt spray; salt tolerance; halophytes; salt damage.

Trees can be exposed to salt in several ways. They may seed or be planted into sodic soils, they may have roots drenched with saline irrigation water or deicing salt runoff, and they may be sprayed with salty ocean water or water from deiced highways. During hurricanes, salt spray damage has been reported on plants $80 \mathrm{~km}$ (50 mi) from the Atlantic Ocean (Pirone 1959), although most damage is said to occur within approximately $300 \mathrm{~m}(1,000 \mathrm{ft})$ of the ocean (Sinclair et al. 1987).

The salt level of straight seawater from the Atlantic Ocean is reported to be approximately 32,000 to $33,000 \mathrm{mg} / \mathrm{L}$ (ppm). Halophytes, plants classified as salt tolerant, can usually tolerate as much as $40,000 \mathrm{mg} / \mathrm{L}$ (ppm) salt (Carter et al. 1989). Salt damage to tree leaves generally becomes visible after sodium or chloride concentrations reach a certain threshold level in the leaf and/or stem tissue, with the chloride ion being the more phytotoxic of the 2 (Sinclair et al. 1987; Williams and Moser 1975). The threshold level can be reached with 1 or 2 high- level or several low-level depositions, with severity of damage increasing with salt concentration.

Symptoms of aerial salt damage to trees are numerous, with many being similar to symptoms of drought and air pollution. The most frequently seen symptoms from direct salt deposition on aboveground tree parts are delayed bud break, reduced leaf size, desiccation of leaf margins and tips, premature defoliation, premature fall coloration, bud and stem kill or dieback, and reduced shoot growth (Figure 1). Excessive twigginess (witches' broom) may develop from adventitious or previously dormant buds that grow after terminal buds are killed. Damage is generally due to increasing osmotic pressure differences that cause tissue dehydration or desiccation, accumulation of specific ions in toxic concentrations $(\mathrm{Na}, \mathrm{Cl})$, and/or altered mineral nutritional balances (Hootman et al. 1994).

A general crown thinning may occur as salt buildup in the soil causes soil structure destruction and root damage. In addition, trees may be deformed or misshapen due to greater damage on the

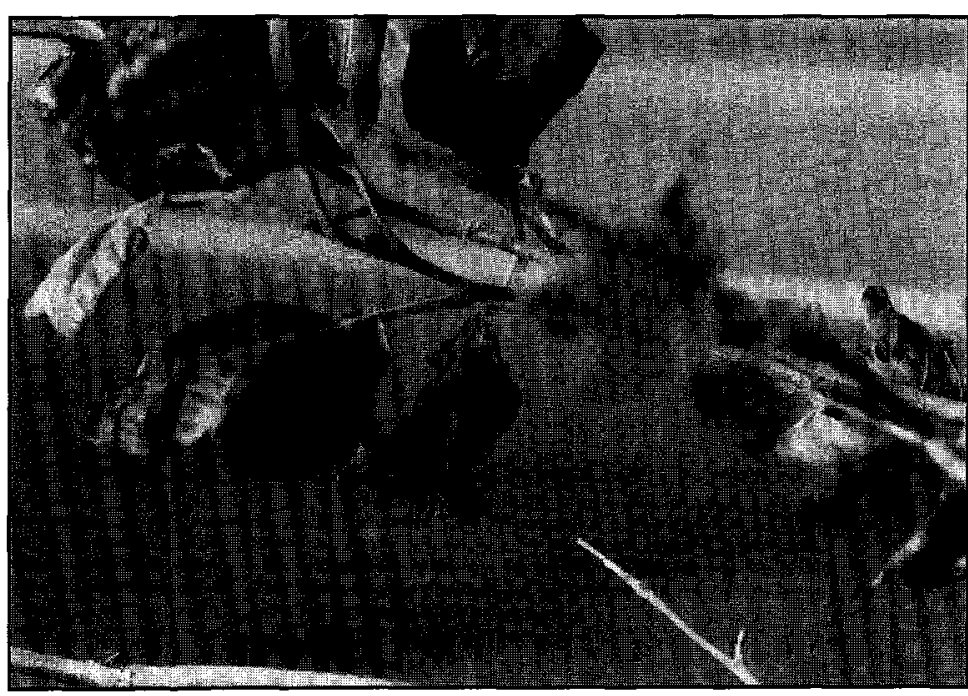

Figure 1. Saltwater spray desiccation of leaf margin and tip on London planetree growing along Atlantic Avenue. 


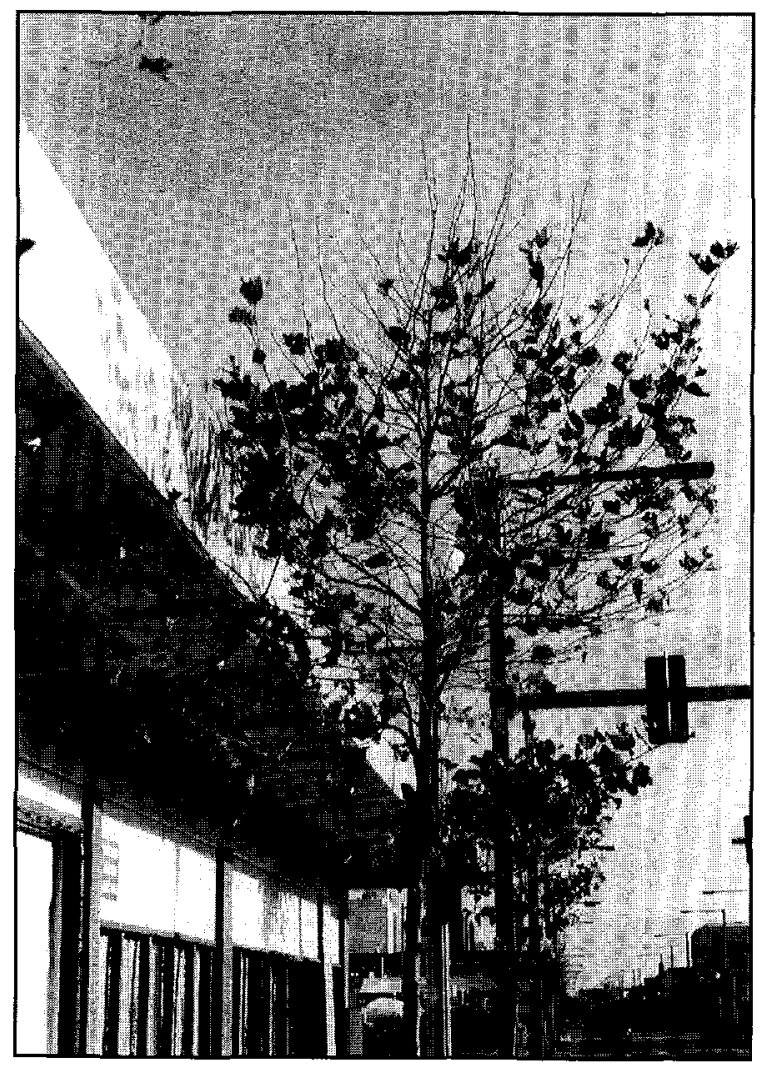

Figure 2. Saltwater spray defoliation of tops of London planetrees along Atlantic Avenue where tree heights exceeded protective building heights. change or lessen the sodium chloride content of oceanwater spray. Therefore, in selecting landscape trees for areas exposed to oceanwater salt spray, it is necessary to find species that will remain aesthetically acceptable after repeated salt spray exposure.

Virginia Beach is one of the largest cities located on the coast of the Atlantic Ocean. Tourism is a major industry for Virginia Beach and therefore the appearance of the city, and in particular the resort area bordering the Atlantic Ocean and Chesapeake Bay, are of utmost importance. Atlantic Avenue, the closest street to the ocean, is the major thoroughfare of the resort area and is bordered by hotels, restaurants, and stores that separate it from the ocean and boardwalk. It was estimated that the city hosted 2.5 million overnight visitors who spent US\$527 million in 1997 (Anonymous 1999).

While major landscaped areas-planted mainly with salt-tolerant shrubs, ornamental grasses, ground covers, and perennials-are used along the boardwalk, areas for landscaping along Atlantic Avenue are very restricted by hardscape. Over 600 inground pits originally designed and designated for tree planting extend the length of Atlantic Avenue and its side streets. Trees planted in these pits are subject to a variety of restrictive conditions common to most street tree planting areas. The areas have limited above- and below-ground growing space,

side facing the wind, or where trees stand taller than partially protective buildings (Figure 2). A damage gradient is often obvious with trees showing less injury the farther they are from the saltwater source (Figure 3).

Trees native to highly saline environments either tolerate or cope with salt using a variety of defenses. Morphological adaptations include specialized salt-secreting glands; penetration-resistant anatomical adaptations include resinous buds and waxy leaves and stems; and salt exclusion anatomical adaptations include smooth twigs, sunken buds, and low surface-to-volume ratios (e.g., pine needles) (Kelsey 1998).

Whereas the composition of pavement deicing products can be changed and chemicals less phytotoxic than sodium chloride used, there is no practical way to

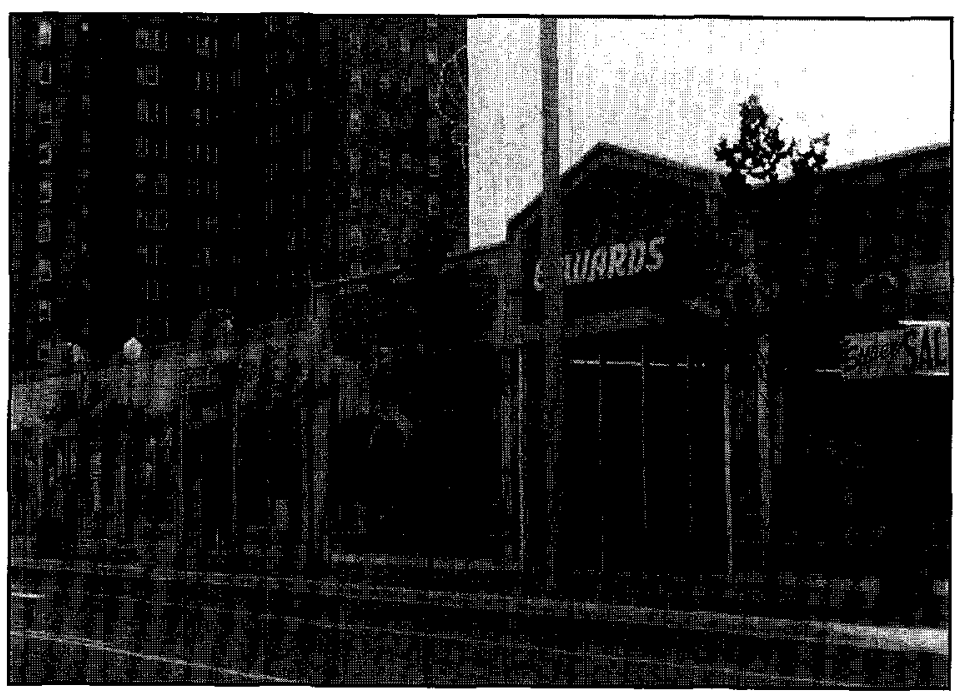

Figure 3. A damage gradient on London planetree along Atlantic Avenue from more exposed sites ( 2 trees, left) to less exposed sites ( 2 trees, right). 
soil is compacted, automobile emissions are extremely high, and vandalism is a constant problem. In addition, several restrictive conditions are imposed by the City of Virginia Beach relative to trees planted along Atlantic Avenue. Trees must provide shade, no tree parts or litter (cones, thorns, etc.) can be hazardous to visitors, and no trees can obstruct vehicular or pedestrian traffic.

Though not a restriction of the City of Virginia Beach, one additional environmental obstacle-tolerance to saltwater spray-has made selection of trees for Atlantic Avenue very difficult. Trees located along Atlantic Avenue are frequently subjected to saltwater spray carried by "nor'easters"-storms whose winds blow from a northeasterly direction across the Atlantic Ocean towards the shore, with wind velocities capable of reaching $105 \mathrm{~km} / \mathrm{h}(65 \mathrm{mph})$. Nor'easters occur any time of year, and multiple nor'easters, particularly during spring, are common.

The major tree species planted along Atlantic Avenue since 1988 has been Platanus $\times$ acerifolia 'Bloodgood' (Bloodgood London planetree). Though the species is rated as moderately salt tolerant on many published lists, most authors did not specify whether the tolerance is to salt spray on aerial plant parts or to salt deposited on the soil. Gibbs and Palmer (1994) listed London planetree as the most severely damaged by road salts in London, while Van Arsdel (1996) listed American sycamore, one parent of London planetree, as being susceptible to salt in irrigation water.

Yearly replacement of as many as 150 trees at costs totaling US\$10,000 to $\$ 12,000$ has been necessary due to severe salt injury and dieback that renders trees aesthetically unacceptable. Many trees eventually die completely despite efforts to reduce injury by washing salt from the leaves as soon as possible after nor'easters pass through the region. The objective of this study was to evaluate trees in the actual adverse environment to determine which species might possess aesthetically acceptable tolerance to nor'easter salt water spray and therefore be suitable for planting along Atlantic Avenue.

\section{MATERIALS AND METHODS}

A list of trees potentially tolerant of aerial salt from either deicing salt drift or seawater spray was prepared after an extensive search of the literature (Foley 1965; Lumis et al. 1973; Dirr 1976; Flint
1983; Schmidt 1983; Siegendorf 1984; Carter et al. 1989; Wyman 1990; Chaplin 1994; Anonymous 1995; Russell 1995; Connors 1996; Delahaut and Hasselkus 1996; Tenenbaum 1996; Gilman 1997; Watson and Himelick 1997). Unfortunately, many authors did not specify whether resistance was to soil salts or salt spray, and many trees that are resistant to soil salts may not be resistant to salt spray. In general, salt spray causes far more injury than do excess soil salts (Lumis et al. 1973). The list was then reviewed to select trees reported to be hardy (cold and heat) for USDA Hardiness Zone 8a and that met "normal" and "Atlantic Avenue" street tree restrictions. Numerous trees that are normally hardy in Virginia Beach and that were listed as being salt tolerant were eliminated from consideration for a variety of reasons (Table 1 ).

On a windy day in October 1995, all tree pits were individually rated for wind exposure and recorded on a map showing all Atlantic Avenue tree

Table 1. Potentially saltwater spray tolerant trees deemed inappropriate for planting along Atlantic Avenue for various reasons.

Aesculus hippocastanum-Horsechestnut (not heat tolerant, too large)

Ailanthus altissima--Tree of heaven (fruit litter)

Ilex chinensis, I. opaca-Chinese and American

hollies (spiny leaves)

Juniperus virginiana-Eastern red cedar (not a shade tree, insects)

Morus spp.-Mulberries (fruit litter)

Nyssa sylvatica-Blackgum (too large)

Picea pungens-Colorado spruce (not heat tolerant)

Pinus thunbergiana-Japanese black pine (sharp needles, cones, nematodes)

Populus alba-White poplar (weak wood, invasive roots)

Prunus spp.-Flowering cherries (insects)

Quercus phellos-Willow oak (too large)

Quercus virginiana--Live oak (difficult to transplant, leaf and fruit litter)

Robinia pseudoacacia-Black locust (thorns, insects, sucker growth)

Sabal palmetto-Cabbage palm (not cold hardy)

Taxodium disticum-Baldcypress (too large)

Ulmus pumila-Siberian elm (insects, weak wood)

Washingtonia robusta-Washington palm (not cold hardy) 
pits. For simplicity, and due to the gusty nature of wind along Atlantic Avenue, an arbitrary rating scale of 1 to 3 was developed: 1 = low exposure-wind blocked by buildings; 2 = moderate exposure-some wind blockage; 3 = high exposure-wind not blocked, or wind tunneled by buildings. Of 605 tree pits, $9 \%$ rated $1,8 \%$ rated 2 , and $83 \%$ rated 3 . Buildings created unexpected tunneling effects that often resulted in higher exposure ratings than anticipated. Gusts blowing in other than the normally prevailing northwest direction were often encountered.

City blocks containing a minimum of 3 planting pits of each wind exposure rating were selected for planting. The first trees were planted from November 1995 to February 1996, consisting of 1 block each of Eriobotrya japonica (loquat), Koelreuteria paniculata (goldenraintree), Liquidambar styraciflua 'Rotundiloba' (fruitless sweetgum), and Ulmus parvifolia 'King's Choice' (lacebark elm). In December 1996, the block of heavily damaged loquat was removed and replaced with Koelreuteria bipinnata (Chinese flametree). A block of Magnolia grandiflora 'Little Gem' (dwarf southern magnolia) was added January 1997, and a block of Gleditsia triacanthos var. inermis 'Shademaster' (thornless honeylocust) was added March 1997. Three partial block plantings of Magnolia virginiana (sweetbay magnolia) were added November 1997. Trees were planted according to the City of Virginia Beach's planting specification, and received supplemental irrigation on a regular basis.

\section{RESULTS}

Defoliation by nor'easters in late August through late October 1996, prior to trees becoming fully dormant, resulted in partial releafing by the goldenraintree, lacebark elm, and sweetgum in exposures 2 and 3 . For all 3 species, the late-season leaf growth was subsequently killed by cold in November and December 1996, resulting in dead terminal buds and twig dieback, and late and limited leafing out the following spring. Similar damage occurred the following year and was compounded by several early spring nor'easters that caused severe leaf damage and defoliation as trees were leafing out. All 3 species, following a second year of evaluation, were deemed aesthetically unacceptable.

The leaves of the loquats incurred severe salt damage throughout summer 1996 in exposures 2 and 3, though loquats located further inland in the city showed no similar damage. In addition to the aesthetic distraction of leaf damage, concern for winter salt dehydration of the dormant buds, and possible winter hardiness reduction (Delahaut and Hassselkus 1996) to this marginally hardy species, led to removal and replacement after only 1 year. The replacement, the more southern species of Koelreuteria, sustained damage similar to the more northern species and was likewise deemed aesthetically unacceptable.

The honeylocusts, listed among the most salt-tolerant trees (due probably to their waxy stems and sunken buds [Dirr 1976; Guy 1996]), were severely damaged as the trees broke dormancy in spring 1997. Terminal dieback was severe enough to necessitate heavy pruning that left most trees with aesthetically unacceptable crowns.

The waxy cuticle on the leaves of the evergreen southern magnolias is reported to make them less sensitive to aerial salt than to soil salt (Van Arsdel 1996). Despite this fact, neither the 'Little Gem' southern magnolia nor the deciduous sweetbay magnolia proved adequately tolerant of wind containing saltwater spray.

\section{CONCLUSIONS}

Because we have no control over when storms occur or how much salt will be deposited, tree species to be used in this harsh environment must be tolerant of saltwater spray at any time of the year. A recommendation for pre-storm protection is the application of an antidesiccant (Tenenbaum 1996), but antidesiccants have not proven effective in preventing salt injury even at higher-than-recommended rates (Dirr 1976). In addition, post-storm washing off of deposited salt is recommended (Siegendorf 1984; Tenenbaum 1996). The City of Virginia Beach tried washing the salt off of London planetrees after storms, but those efforts proved relatively ineffective. To be able to immediately wash off all oceanfront trees after every exposure to salt water spray is impossible, and therefore there appear to be no cultural practices to use to try to reduce or prevent deposition of salt on and accumulation of salt into buds, leaves, and stems. 
Frequent replanting is no longer economically acceptable to the City of Virginia Beach. Because there are no species sufficiently tolerant to saltwater spray and because no realistic cultural techniques for dealing with salt deposition appear to exist, the authors recommended to the manager of the City of Virginia Beach that all sites with moderate and high exposure ratings not be replanted with deciduous trees. Instead it was recommended that the City of Virginia Beach use a variety of tree-form or pleached shrubs (such as Myrica cerasifera, southern waxmyrtle), ground covers, and annuals that have already proven their salt tolerance along the boardwalk or Atlantic Avenue. Providing the level of shade desired for tourists appears to be impossible under the adverse conditions of the city's main tourism thoroughfare.

\section{LITERATURE CITED}

Anonymous. 1995. Listing trees shown to be salt-tolerant. Landscape Manage. 34:38.

Anonymous. 1999. Marketing Overview. Virginia Beach Tourism Fiscal Year 1999.

Carter, S., M. Yoklic, and C. Schaefer. 1989. Landscaping with salt-tolerant material. Am. Nurseryman. 170:8899.

Chaplin, L.T. 1994. The Southern Gardener's Book of Lists. Taylor Publishing Company, Dallas, TX. 186 pp.

Connors, M.S. 1996. At the ocean's edge. Horticulture LXXIV:34-38.

Delahaut, K.A., and E.R. Hasselkus. 1996. Salt injury to landscape plants. Univ. of Wisc. Coop. Ext. Pub. A2970.

Dirr, M.A. 1976. Selection of trees for tolerance to salt injury. J. Arboric. 5:209-215.

Flint, H.L. 1983. Landscape Plants for Eastern North America. John Wiley \& Sons, New Yori, NY. 677 pp.

Foley, D.J. 1965. Gardening by the Sea from Coast to Coast. Parnassus Imprints, Orleans, MA. 285 pp.

Gibbs, J.N., and C.A. Palmer. 1994. A survey of damage to roadside trees in London caused by the application of de-icing salt during the 1990/91 winter. Arboric. J. 18:321-343.

Gilman, E.F 1997. Trees for Urban and Suburban Landscapes. Delmar Publishers, Albany, NY. 662 pp.

Guy, R. 1996. Pour on performance, profits with de-icing salt. Landscape Manage. 35:SR17-SR18.
Hootman, R.G., P.D. Kelsey, R. Reid, and K. von der Heide-Spravka. 1994. Factors affecting accumulation of deicing salts in soils around trees. J. Arboric. 20:196-200.

Kelsey, P. 1998. Personal communication.

Lumis,G.P., G. Hofstra, and R. Hall. 1973. Sensitivity of roadside trees and shrubs to aerial drift of deicing salt. HortScience 8:475-477.

Pirone, P.P. 1959. Tree Maintenance. 6th ed. Oxford University Press, New York, NY. 514 pp.

Russell, A.B. 1995. Coastal plants from A to Z. Amer. Nurseryman 182:42-60.

Schmidt, R.M. 1983. Gardening on the Eastern Seashore. Barnegat Light Press, Barnegat Light, NJ. 205 pp.

Siegendorf, L. 1984. Hurricane tree care. J. Arboric. 10:217-221.

Sinclair, W.A., H.H. Lyon, and W.T. Johnson. 1987. Diseases of Trees and Shrubs. Cornell University Press, Ithaca, NY. 575pp.

Tenenbaum F. (Ed.), 1996. Taylor's Guide to Seashore Gardening. Houghton Mifflin Company, Boston, MA. $391 \mathrm{pp}$.

Van Arsdel, E.P. 1996. Leaf scorch: Detecting the cause. Arbor Age 16:22-8.

Watson, G.W., and E.B. Himelick. 1997. Principles and Practice of Planting Trees and Shrubs. International Society of Arboriculture, Champaign, IL. 199 pp.

Williams, D.J., and B.C. Moser. 1975. Critical level of airborne sea salt inducing foliar injury to bean. HortScience 10:615-616.

Wyman, D. 1990. Trees for American Gardens. Macmillan Publishing Company, New York, NY. 501 pp.

Acknowledgements. The authors wish to thank the Virginia Urban and Community Forestry Grant Assistance Program for funding that helped support this research, and crews from Landscape Services of the City of Virginia Beach for tree installation and maintenance.

\section{${ }^{1}$ Associate Professor, ${ }^{3}$ Research Specialist \\ Hampton Roads Agricultural Research and Extension Center \\ Virginia Tech, 1444 Diamond Springs Road \\ Virginia Beach, VA 23455}

\author{
${ }^{2}$ City Arborist, City of Virginia Beach \\ Landscape Services, Municipal Center \\ Virginia Beach, VA 23456
}


Résumé. Les arbres localisés en bordure de la rue longeant la plage principale de la ville de Virginia Beach aux États-Unis sont sujets aux embruns salés provenant de l'océan Atlantique. En dépit du désir de la Ville de planter des arbres pour avoir de l'ombre le long de cette voie publique, aucune des huit espèces considérées comme tolérantes au sel et qui rencontraient les critères de design de la Ville sont demeurées esthétiquement acceptables après un an, autant dans les lieux modérément que fortement exposés au vent. Les espèces expérimentées ont été le néflier du Japon (Eriobotrya japonica), le févier inerme (Gleditsia triacanthos var. inermis), le savonnier à feuille bipennées (Koelreuteria bipinnata), le savonnier ( $K$. paniculata), le copalme d'Amérique (Liquidambar styraciflua 'Rotudiloba'), le magnolia à grandes fleurs (Magnolia grandiflora 'Little Gem'), le magnolia de Virginie (M. virginiana) et l'orme à petites feuilles (Ulmus parviflora 'King's Choice').

Zusammenfassung. Die Bäume entlang der Hauptdurchfahrtsstrassen in dem Stadtbereich von Virginia Beach sind von Salzwasserdrift betroffen. Entgegen dem Plan der Stadt, entlang dieser verkehrsader Schattenbäume zu pflanzen, war keine der acht Arten, die als salztolerantempfohlen und den Designvorstellungen der
Stadt entsprachen, nach einem Jahr an einem durchschnittlichen, dem Wind stark ausgesetzten Standort, für die Stadt ästhetisch akzeptabel. Folgende Arten wurden getestet: Eriobotrya japonica, Gleditia triacanthos var. inermis, Koelreuteria bipinnata, $K$ paniculata, Liquidamber styraciflua Rotudiloba, Magnolia grandiflorum Little Gem, $M$. virginiana und Ulmus parviflora King s Choice.

Resumen. Los árboles que crecen a lo largo de la principal área pública turística de la ciudad de Virginia Beach en los Estados Unidos están sujetos a la aspersión de la sal del agua del Océano Atlántico. A pesar del deseo de la ciudad de plantar árboles para sombra a lo largo de esta área pública, ninguna de ocho especies que fueron reportadas como tolerantes a la sal y que reúnen los requerimientos del diseño, fueron estéticamente aceptables, después de un año, en ubicaciones de exposición al viento moderadas y altas. Las especies probadas fueron níspero (Eriobotrya japonica), acacia (Gleditsia triacanthos var. inermis), árbol chino (Koelreuteria bipinnata), lluvia de oro (K. paniculata), liquidámbar (Liquidambar styraciflua 'Rotudiloba'), magnolia sureña injertada (Magnolia grandiflora 'Little Gem'), magnolia (M. virginiana), y olmo (Ulmus parviflora 'King's Choice). 